\title{
REHABILITATION OF GEOGRAPHICAL AREAS FOR A TOURIST DEVELOPMENT THE CASE OF BATNA REGION'S MOUNTAINS (ALGERIA)
}

\author{
Louardi KHERROUR* \\ Houari Boumediene Sciences and Technology University, Department of Geography and Territorial \\ Planning, BP 32, El Alia, Bab Ezzouar, 16111, Algiers, Algeria, e-mail: louardi.kherrour@yahoo.fr
}

\section{Mohamed A. REZZAZ}

Houari Boumediene Sciences and Technology University, Department of Geography and Territorial Planning, BP 32, El Alia, Bab Ezzouar, 16111, Algiers, Algeria, e-mail: drezmas@yahoo.fr

\section{Sofiane HATTAB}

Houari Boumediene Sciences and Technology University, Department of Geography and Territorial Planning, BP 32, El Alia, Bab Ezzouar, 16111, Algiers, Algeria, e-mail: sofianeht@yahoo.fr

Citation: Kherrour, L., Rezzaz, M. A., \& Hattab, S. (2018). REHABILITATION OF GEOGRAPHICAL AREAS FOR A TOURIST DEVELOPMENT THE CASE OF BATNA REGION'S MOUNTAINS (ALGERIA). GeoJournal of Tourism and Geosites, 22(2), 455-469. https://doi.org/10.30892/gtg.22215-302

\begin{abstract}
The rugged mountains of the province of Batna suffer an isolation which explains the poverty of the population and the precariousness of their living conditions. If rural and urban spaces require scientific methods for their organization and their development, mountain areas also need planning and productive development through the integration of tourism in a context of economic benefit. To this aim, our topic emphasizes the enhancement of site rehabilitation by focusing on tourism demand, within the framework of a participative and decentralized approach allowing the various actors to be involved in the decision-making processes concerning tourism, enhancement and preservation of touristic potentialities and all the territorial values of this mountainous area. This article also concluded that the feasibility study represents a tool that plays an important role in the evaluation process and determines the effectiveness of an investment project in different areas: environmental, legislative, social and financial. In drafting such an important research towards the development of this region's tourism industry, a descriptive approach was used to highlight the true image of the studied sites and the importance of their development in order to contain tourist activities connected to mountains. Followed by a conceptual approach to rehabilitate four sites and adapt them to geological, geomorphological and environmental tourism.
\end{abstract}

Key words: Batna Mountains, Algeria, mountain tourism, sustainable development, natural and cultural heritage

\footnotetext{
* Corresponding author
} 


\section{INTRODUCTION}

Algeria is a rich country with a diversified touristic base, but unfortunately it is not exploited in the right way. At the same time, it aims to become a coastal tourism destination with $1.200 \mathrm{~km}$ of sunny coastline all year long and about thirty capes and many beaches. It also intends to be a destination of green tourism with plains, forests, peaks and highlands, and an exotic destination with the second largest desert in the world and some sand dunes (oases), and of course a destination of cultural and historical tourism with its cities that have a remarkable heritage and a particularly rich and diversified past. Algeria is full of historical, archaeological and natural landscapes to discover. It is, after Italy, the richest country with splendid vestiges of the Roman era (Bezza, 2006). But unfortunately, many wonderful beaches, splendid forests, old villages and places submerged with history are nowadays ignored not only by tourists but also by the inhabitants themselves. Much closer than one can think, two hours by plane from the main cities of Europe, Algeria has the assets of a full-fledged destination: a marvelous climate, an exceptional tourist capital and an ideal geographical position, but unlike other countries around the Mediterranean Basin, Algeria has not yet given the tourism sector an important role in its various development policies (Nassima, 2013). Today, Algeria is timidly involved in international tourism and resigns to occupy the last ranks of tourist destinations in the Mediterranean basin. In international tourist flows terms, Algeria welcomed 2394887 tourists during year 2011, 65.35\% of which are Algerians living abroad (Kouache, 2004). The 2011-2012 Economic Outlook of the Mediterranean Tourism Organization shows that the Mediterranean countries received in 2011 are approximately 300 million international tourists, or $30.52 \%$ of the tourists traveling in the world (the international tourist arrivals in the world amount to 982.2 million). Algeria's share in this market is so minimal that it does not even appear in the ranking of this organization (Bouakrif, 2012). The capacity of tourist reception has developed reaching the threshold of 80000 beds in 2010 following the advent of investment laws, and the goal of Algeria to adopt the economic reform plan at the dawn of the nineties. But, nevertheless, such figure remains very poor compared with that achieved in Tunisia, Morocco and Egypt which secured during the same year 240000 beds in Tunisia, 164000 in Morocco and 430000 in Egypt (Hammad, 2012). Compared with some of the Mediterranean countries mentioned above, the tourism indicators studied show that Egypt welcomed more than 14 million tourists in 2010, while Tunisia and Morocco welcomed 6.9 and 8.5 million tourists, and Algeria has only welcomed 2 million tourists in the same year. Italso shows that tourism contributes enormously to the economic development, since Egypt had earned more than $\$ 10$ billion of revenue from tourism in 2009. Tunisia and Morocco recorded respectively $\$ 3.47$ and $\$ 6.55$ billion in the same year, while Algeria earned only $\$ 0.33$ billion. Thus tourism in Egypt contributed with $7.3 \%$ of the whole local product during 2011, and contributed in Tunisia and Morocco with respective averages of $8.2 \%$ and $8.5 \%$, while it contributed with $3.7 \%$ to Algerian total national product in the same year (Aouinene, 2012). Hence, Egypt, Tunisia and Morocco have occupied the first places in North Africa, while Algeria is among the last, which shows, indeed, that the tourism sector in Algeria is slightly far from tourism sectors of the Mediterranean countries mentioned above. This is due to one main reason, Algeria has concentrated its economic activity on the hydrocarbon sector, relying more on its oil and gas resources.

Indeed, the incomes of the oil profits have always made the contribution of tourism to the Algerian economy not really sought, despite the delimitation and the study of 205 areas and sites of tourism expansion since 1966 to 2008. Yet, the three countries mentioned above (Egypt, Morocco and Tunisia) became aware of their tourism, coastal, mountain and Saharan potentials, as well as archaeological sites and land by building basic structures in order to promote tourism. 
Plus, it should be noted that certain sociocultural factors that have emerged in recent years complicate the situation of the sector due to social degeneration caused by insecurity, delinquency, job instability and inflation. Regarding this, it is necessary on the one hand to adjust the social and security situation before starting any action to promote tourism, and on the other hand, any approach to tourism development should take into consideration the socio-cultural specificity, as well as the traditions and the cultures of the most affected local populations (Boutafenouchet, 2011). With regards to the market emitting tourists that Algeria plans to invest, it stands out first, the European market (France, Germany, Spain, Switzerland and Scandinavian countries) and the Asian market especially China. Algeria recognizes that tourism is the alternative solution to the development of its economy by establishing a master plan for tourism development by 2025. Within the framework of its general policy in setting out the targets of tourism development, Algeria emphasized on some priorities, by increasing its capacity and programming certain projects in its coastal areas. This means that it still supports the old policy based on seaside tourism, which is very poor. The public policy of tourism development is incompatible in terms of programming and orientation. Developing tourism has been focused on the coast and the international tourism movement to the south, particularly in the regions of Tassili and Ahaggar, setting aside the inland regions, rich with natural and human tourist potential, which have not been equipped with a tourism development strategy. This strategy does not consider all these regions to be tourist poles, in accordance with the law № $10-02$ of June 29, 2010, approving the National Plan of Spatial Planning. Consequently, the idea of the present research highlights a case of one of the interior regions, which is the case of the Batna province, with the aim of demonstrating that the tourist development plan of the territory must necessarily go through the stage of the total diagnosis of tourism potentialities, then the analysis of the data, to arrive at a general conception of the territorial plan of the tourist development.

To this end, our study highlights an inventory of the tourist potentialities of the province of Batna, insofar that this region offers an actual opportunity for the practice of mountain, rural, geological and environmental tourism. Targeting the provision of essential equipment and devices for the development of certain sites of this province, we studied this topic in the context of our research entitled "Rehabilitation of geographical areas toward tourism development, Batna region's mountains as a template”.

\section{METHODOLOGY}

The study was based on descriptive analytical and conceptual methods to project the design models that correspond to natural tourist sites. First, after examining the potentialities of mountain sites, in coordination with the representatives of tourism sector at the Tourism Directorate of the province of Batna and officials from municipalities to which these sites belong, we found a lack of reception facilities that attract tourists. Then, we chose the cave of "Sidi Mohamed Ben Taher", the source of fresh water "Ain Oucherchar", the canyons of "Berbagga" and the folds of Djebel "Elmahmel", and designed structures that fit into natural sites suitable for geological, geomorphological and ecological tourism. We used the ArcGIS program and the Architectural Photoshop program for mapping the rehabilitation of planned sites. Finally, we took the ecotourism project as a model for financial study, in order to identify its economic feasibility and investment benefits.

\section{THE ALGERIAN STATE'S VISION OF TOURISM}

The State's commitment to the development and implementation of integrated tourism and administrative policies, as well as the establishment of conditions for 
promotion, is the key instrument for tourism development and the key factor in supporting tourism and economic growth. This innovative approach requires an implementation based on material actions likely to enhance the touristic contribution within the development scheme of the region. Thus, tourism is called to reorganize itself, to transform itself and to deploy itself to become the second largest exporting economic activity after hydrocarbons. To this aim, the objectives set for the launch of tourism in Algeria are reflected by: the strong will of the state to enhance the natural, cultural and historical potential of the country and to enhance its tourist heritage. On long term, it's about making tourism a development-enhancing industry. The launch of the first tourism poles of excellence (TPE) and the first tourist villages of excellence (TVE) integrated as priority projects and levers of tourist initiation constituting, since 2008, the priority tourist action programs. Priority tourism projects begun in 2008, the launch of tourism in Algeria in a partnership development framework that must involve the State, local authorities, foreign direct investment (FDI), public sector professionals and the private sector, the education system and all the other economic sectors; as well as the associations (Ministry of the Spatial Planning of Environment and Tourism, 2008).

\section{GEOGRAPHICAL OUTLINE}

The region of Batna lies between $4^{\circ}, 7^{\circ}$ east longitude and $35^{\circ}$ and $36^{\circ}$ north latitude (Fig.1). This situation has an importance on climate and vegetation cover that enriches tourism, a mountainous nature, a cold winter and moderate summer.

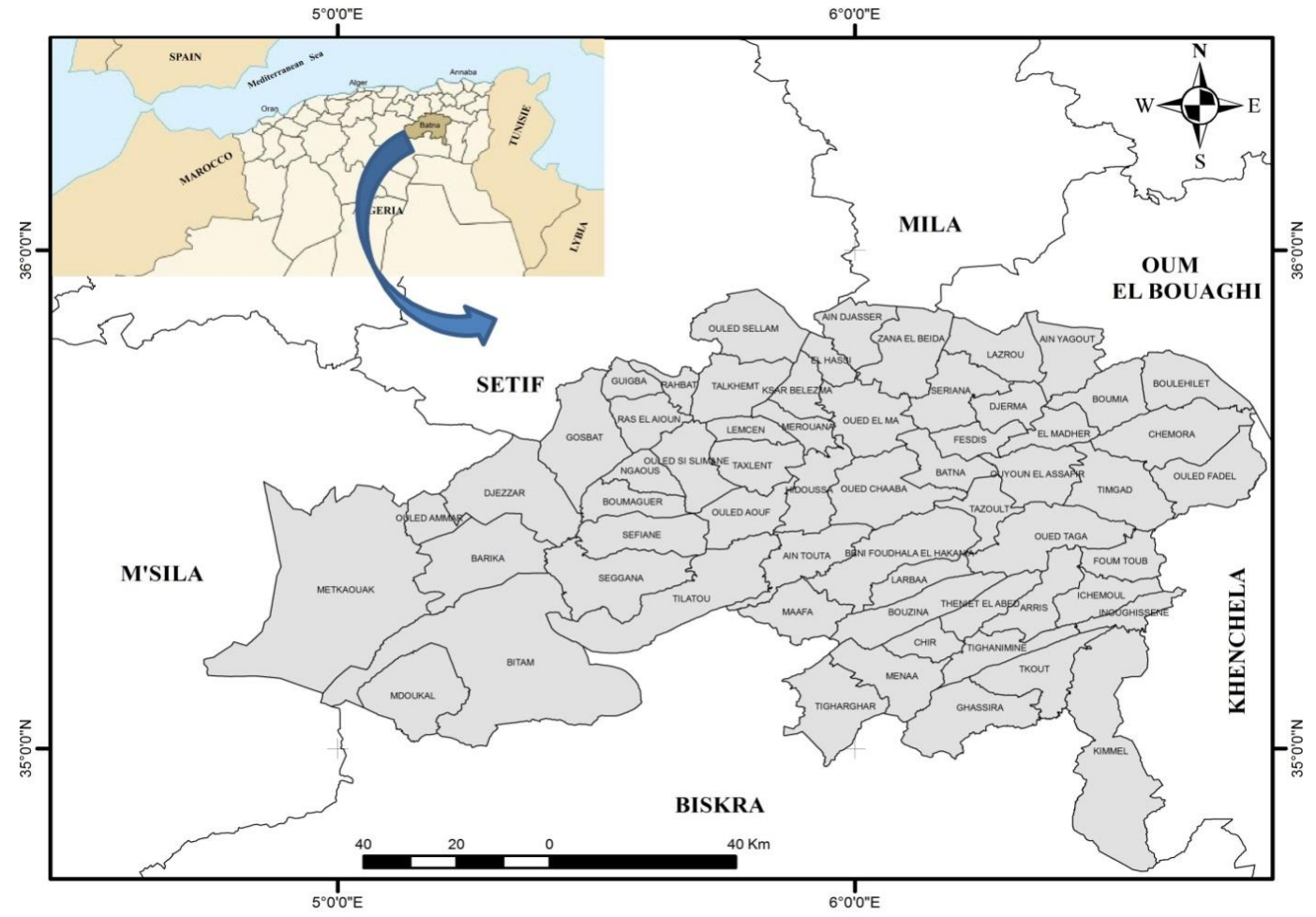

Figure 1. Sketch of geographical location of the study area

The province of Batna was part of one of the Aures dairas. At the administrative division of 1974 the province gathered 34 communes under cover of 6 daïras (KAIS, 
ARRIS, KHENCHELA, AIN TOUTA, MEROUANA and BARIKA). At the administrative division of 1984 the limits of the province have experienced important changes, the attachment of 5 of the 34 municipalities to the provinces of Biskra and Khenchela. Redistribution has integrated the municipality of ELDJEZZAR of the province of M'sila to the province of Batna which counted then 61 municipalities distributed on 22 daïras. The province of Batna covers an area of $1203876 \mathrm{Km}^{2}$, limited by the province of Mila on the North, Biskra on the South, Oum el-Bawaghi on the Northeast, on the East Khenchela, province of M'sila on the west and in the northwest the province of Setif.

\section{STRATEGIC INTEREST OF A MOUNTAINS TERRITORY}

The mountains of developing countries are the subject of many attentions from researchers and public authorities and international organizations, who emphasize the biodiversity of these spaces but also the poverty of a large part of their inhabitants and the environmental and socio-economic issues raised by the recent deployment of tourism. Many actors are now involved at all scales to influence the future of these mountain territories in particular through the establishment of protected areas and the encouragement of sustainable development of tourism (Isabelle, 2009). In the territory of the province of Batna, the mountains represent nearly $45 \%$ of its total area (12 $\left.03876 \mathrm{~km}^{2}\right)$ and are home to a population of more than 700 ooo inhabitants in 44 mountain municipalities. With its $324915 \mathrm{Km}^{2}$ of forests, its immense alpine meadows and its many native species (09\% of the species listed locally), it represents an enormous reserve of biodiversity and an original natural heritage (Houamel, 2012). The mountains of the province of Batna, east of Algeria, occupy an important place in environmental and cultural terms within the massifs of the Aures. They contain important and various potentialities that make them a territory of strategic interest coveted by different actors. In this region tourism has many issues and interests on both the local population and the various development actors. They can be seen as a new element of economic and social development in the region. Still, several questions arise about the conditions necessary for the establishment of a sustainable tourism development that could boost these enclave and deprived areas (Benzeroual, 2006). Given its potential and the values it contains (mineral resources, biological resources, sites and landscapes, tourism, sports, intangible heritage and local know-how); we notice that the mountain economy in Aures remains undeveloped. The weakness of infrastructure and equipment as well as the lack of investment has favored the migration of the mountain population, leading to erosion and loss of this rich cultural and natural heritage. These mountains are also home to traditional agriculture that contributes to the shaping of valley landscapes. More recently, tourism, which is being developed thanks to the existence of Ghoufi's natural balconies and hiking activities throughout the Mahmel Massif, the highest point in Batna, has been added to agro-pastoral activities. This tourism is, for many individuals remained on the spot, and used as guides, archaeologists, festival managers and salesmen, the principal means of payment. The integration of tourism activity is one of the main changes of recent years. Seasonal migration of the city labor force is also a complementary source of income.

\section{AN ENCLAVE AREA AND A DEPRIVED POPULATION}

The mountains of the province of Batna, constitute a distinct geographical entity at the level of the junction of two Atlas (Tellian and Saharan). Structurally, the Tellian Atlas by all the mountains of Hodna, BouTaleb, and the Belezma Mountains, and the Saharan Atlas by Aurès and Mount Metlili, forms the main physical structure of the province and due to this they constitute the most important physical ensemble (Meharzi, 2010). The region of Batna in its south-eastern part is characterized by a semi-arid climate with a 
prolonged hot and dry summer and a cold and rigorous winter where snow falls frequently covering the mountains for several weeks during the months of December and January. The average annual temperature is $15^{\circ} \mathrm{C}$. In its northern fringe the climate is sub-humid with rainfall ranging from $500 \mathrm{~mm}$ to $700 \mathrm{~mm}$ (Kentouche, 2005). Indeed, it is from this part of the Tellien and Saharan Atlas Mountains that the most important rivers of the province emerge (Oued Abdi, Oued El Abiod, Oued Fedhala, Oued Barika and Oued El Gourzi) (Figure 2), but unfortunately these valleys do not reflect the image of eco-tourism due to sewage pollution. As regards the administrative boundaries, as it can be seen from the figure mentioned above, the province is bounded on the north by the province of Mila; in the North-East, by the province of Oum-El-Bouaghi; in the East, by the province of Khenchela; in the South, by the province of Biskra; in the West, by the province of M'Sila and in the North-West, by the province of Setif. Marginal at the national level, this region suffers from a geographical isolation which was further accentuated by historical events. Populations mostly Berber (more than 15 tribes) or Arabized Berber strains (Ouled Ziane and Ouled Deradj) live in uncertain conditions; their activities are based mainly on livestock and food crops. This population is still suspicious of various invasions, and the situation has hardly changed since independence: in terms of language, the references published since 1962 can be counted on the fingers of one hand (Leveau et al., 1990). After independence, and despite the efforts of the state, the region continued to play the same role. It remains disadvantaged and under-equipped compared to the privileged areas of Algeria. The road network remains deplorable despite the rehabilitation of the weak network inherited from the colonial period (Batna-Biskra road through the Amentane gorges) and the creation of certain roads (Batna-Setif by the Belezma Mountains). A large number of towns and rural centers are reached only by difficult roads; towns located on the peaks remain totally isolated.

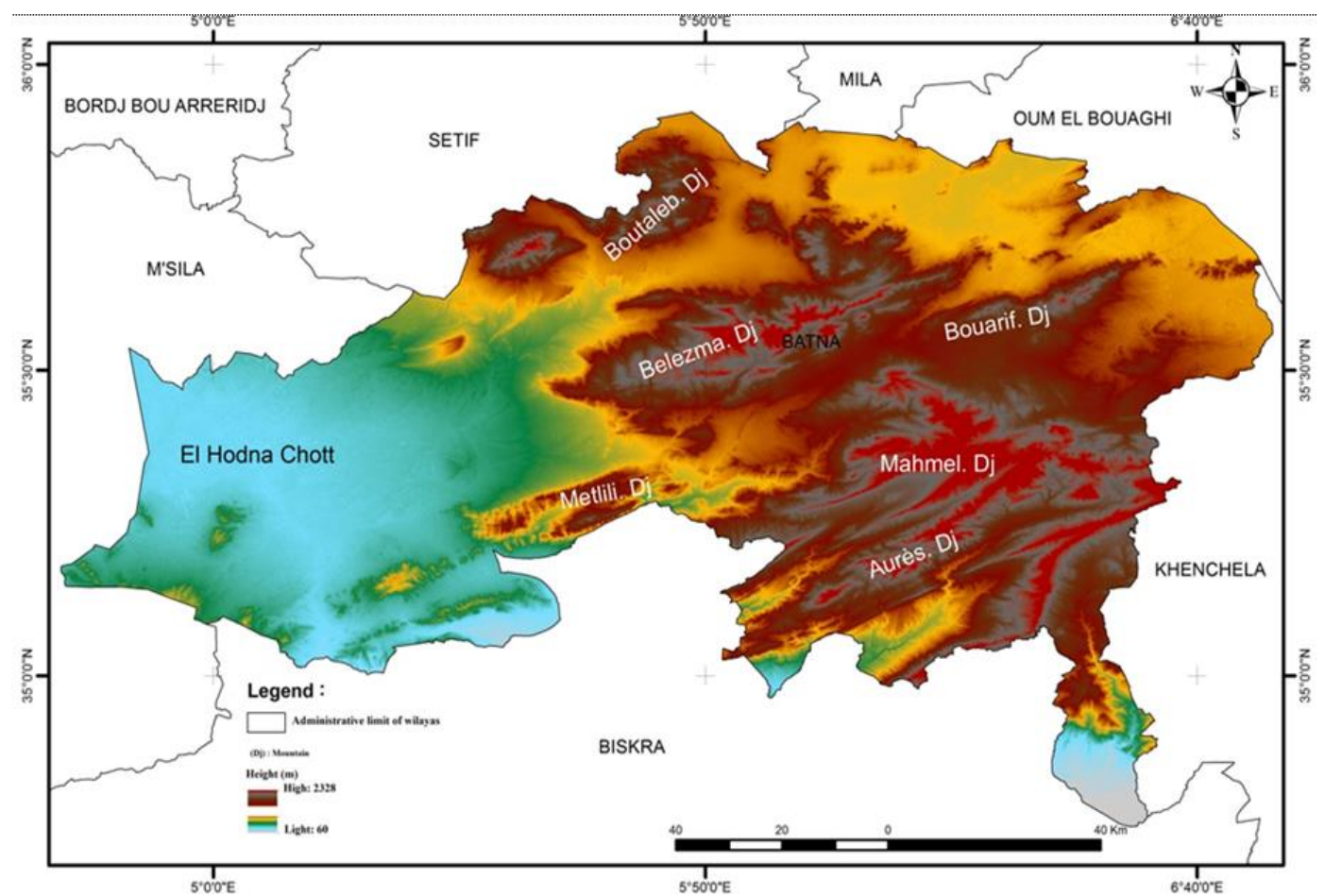

Figure 2. Morphometric map of the different reliefs of Batna province 
The economy of the region remains dominated by agro-sylvo-pastoral activities with low cash flow. Equipment for education and health is also very inadequate. Nevertheless, this part of the Saharan Atlas contains important and diversified natural and cultural potentialities that can constitute a basis for a major tourist development and economic start.

\section{AN UNDERVALUED NATURAL AND CULTURAL HERITAGE}

Regardless the constraints mentioned before, the mountains of Batna province also have specific assets that make it a territory of strategic interests. It's rich with natural resources, human and cultural which constitute a support of very interesting stakes. Beautiful cedars (Cedrusatlantica) are still well preserved at Mount Bourdjem and Mount El Malou. The landscape heritage linked to water and karstic dynamics is an important tourist asset that must be valued. Indeed, the karstic landscapes located everywhere in the limestone formations constitute an undeniable wealth of the region and give it a remarkable identity. The conservation of Batna's forests shows that this region has about 53 known underground caverns, the most important of which are the Khenguet $\mathrm{Si}$ Mohamed-Tahar cave, located on Mount Timagoul at an altitude of more than $1350 \mathrm{~m}$ above sea level in the region of Berbaga in OuedTaga town, this cave was discovered at the beginning of the twentieth century by the French of Italian origin, Jean-Baptiste Capéletti, and it bears since 1969 his name. Or the cave of lions located in the town of Oued El Ma or that of Troglodytes commonly known as a refuge of Dihia.

While the limestone ridges, forming glacis north of the Aures, gave these mountains their ancient reputation as an inaccessible massif, the cliff more or less steep assured a safe haven for the oldest inhabitants: they found, in the middle of a dry country as a whole, water at the foot of the caves, the upper level of the marls, which formed the subsoil of depressions favorable to crops (Joleaud, 1934). The presence of these caves will inspire a working group for, among others, the creation of a caving club. Therefore, the mountains of Batna province are characterized by a clearly visible natural heritage, determined by the presence of a much diversified range of facies and a wide variety of geomorphological structures ranging from folds, gorges and cliffs. Their protection involves all types of preservation and planning measures that contributes to respect for their diversity and natural integrity.

This natural heritage will also allow the development of an ecotourism circuit, through the protection of Geosites which is now an integral part of Geoscience and landscaping. The geosites are landforms with a specific shape, which alone or in collaboration with other bioecological or anthropic elements can become objects of heritage. Scientifically, the geosites are the most clear representation of the geomorphological processes, of the existent relations between the numerous factors which lead to their occurrence (Ilieş \& Josan, 2009). Geotourism has been documented as one of the important strategies to support biodiversity conservation, but its relationship with biodiversity and local people is poor (Hakim \& Soemarno, 2017). Geotourism is a relatively new concept, based on the geological or geomorphological attraction of a site and increasingly involved in regional potential development (Malaki, 2006). In the chain of Aurèsin Mount Bouthlagmine and Kef El Mahmel extend some dry valleys, cones, large canyons and giant sinkholes. Some depressions are occupied by natural gorges such Tighanimine gorges between Arris and Ghoufi. The natural balconies overlooking the valley of Oued El Abiod in town of Ghassira are original in its genesis and the beauty it offers in the middle of the oasis overlooking it.

The built heritage is quite diverse, typical Berber towns are scattered all over the valleys and depressions (oued Abdi and Oued El Abiod) or hung on some slopes (Nirdi- 
Bouzina). Traditional housing reflects a certain integration of local populations into their environment and thus their living conditions and customs. Most of the materials used are local, mostly from the subsoil and the forest. The structures of the houses and their modes of construction reflect the strong cultural identity of the region. Cultural heritage is also important. Aithmimoune town and Aithyahiais located in Ghoufi, a site classified since 1982. The agricultural terraces engraved on the feet of Mount Lazreg (Ouerka, Nara, Hidous) offers remarkable points of view. Traditional irrigation techniques, water resource and environmental management offer considerable tourism values. The production of natural honey and the apple trees as well as olive oil encourages Agrotourism in the region. The folklore of the local tribes is quite rich.

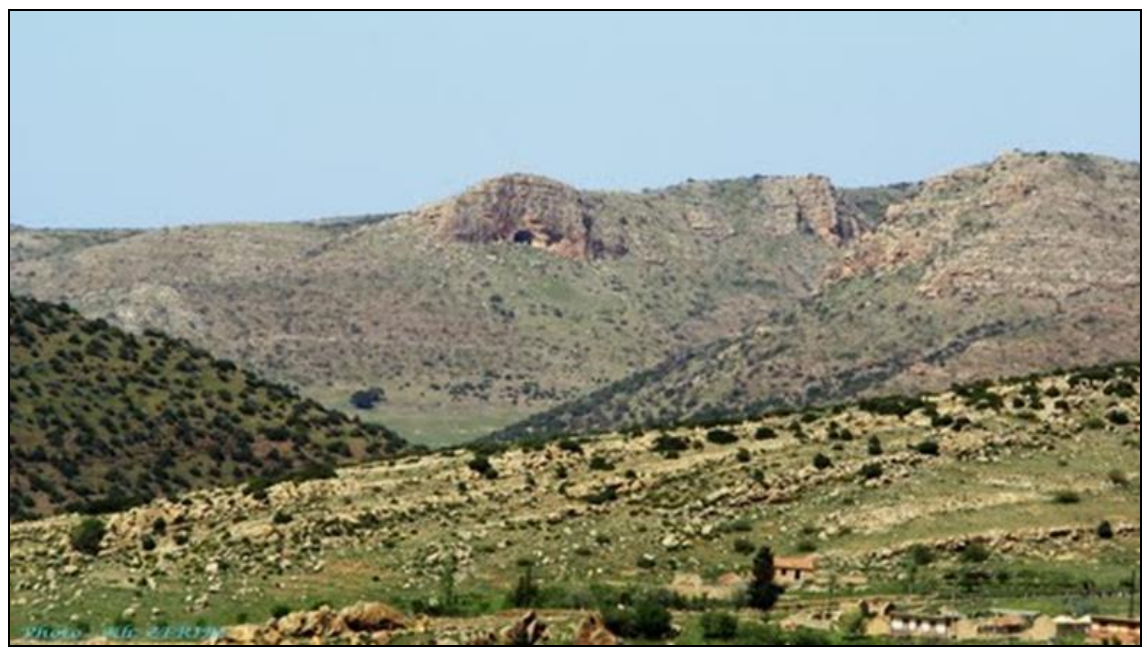

Figure 3. The Cave of "Mouths of stars" in the Mestawa Mountain

This mountainous region is also home to the Belezma National Park, which currently covers an area of 26250 hectares, and offers a great diversity of flora and fauna. Located at the crossroads of the Saharan and Tellian massifs, Belezma plays a role as a biological reservoir favorable to the dispersal and migration of species, the regulation of natural balances and the producer of economic and social resources. The proximity of the vast expanses of forest areas in the Aures Mountains is an extra asset to ensure the maintenance of Belezma's biological diversity (Sahli, 2004). The landscaped paths are thus numerous and attractive; in addition to the 9 trails offered in the Belezma Park (Condorcet-Merouana, Batna-Seriana, Djerma ...); the diversity of landscapes in the region allows to consider other trails to discover a rich natural and cultural heritage (The above figure 3 is one of the Caves among the 9 caves existing in the Batna province). The municipalities of Hidoussa, Merouana, Oued Elma and Seriana offer several possibilities. According to this list of existing potentialities we perceive a great potential for rural tourism in this region, offering visitors a warm welcome among locals, with local cuisine and sports and leisure activities such as hunting and hiking. Besides, the less populated areas of the region (Tafrent, OuedNafla and Merkonda) are rather favorable to itinerant tourism (Figure 4 is the Oued Nafla).

The remarkable sites identified in the various municipalities of the region may constitute centers of interest that could fuel an important ecotourism movement that benefits the local population regarding non-agricultural job creation. Unfortunately, these sites, with the exception of Belezma National Park, are neither enhanced nor protected 
against multiple forms of degradation. Ecotourism has a potentially vital role to play in conservation by generating economic incentives for nature conservation (Lindsey et al., 2007) Moreover, it must be admitted that this potential, so important, is insufficiently known, or even totally ignored in some cases. A great effort of publicity, promotion and development of different potentialities is needed, with the aim of boosting the tourism sector, which could be a catalyst for other economic and social sectors in the region.

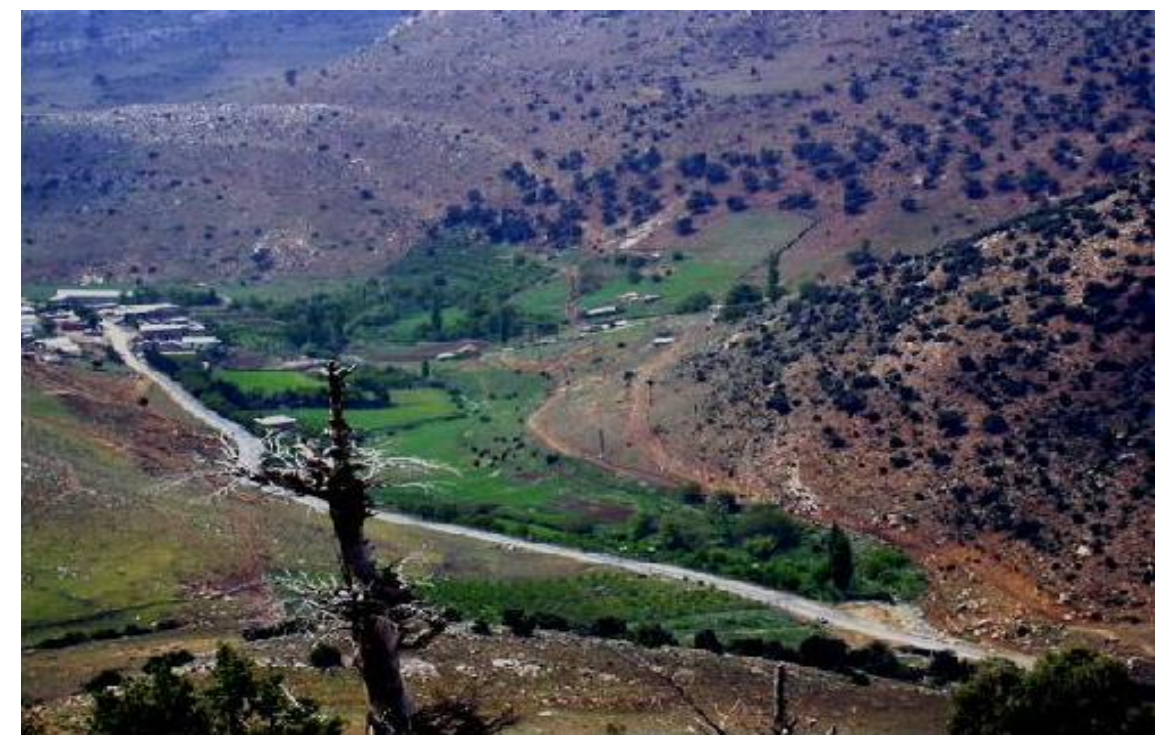

Figure 4: Village of "Nafla" with its terraces in the heart of Belezma National Park

\section{THE BELEZMA NATIONAL PARK (BNP) DEVELOPMENT STRATEGY}

In order to reduce the pressure of indigenous peoples and their flock on protected natural resources, the BNP Administration believes that some development projects should be undertaken for their benefit. The form of programming these projects reflects an acute awareness of the administration of the indigenous population's contribution in the maintenance of natural resources. The annual renewal of these activities over the past ten years indicates that the program objectives have reached a level of success which the administration and its supervision have encouraged. The goal of development programs is to reduce anthropogenic pressure on protected natural resources by seeking alternatives to traditional forms of land use (Sahli, 2004). These operations contribute to the improvement of living standards of rural communities by encouraging their membership. The demand of this type of project is increasing on the part of rural communities. On the ground, there are new agricultural practices that are more profitable than traditional practices but require more work and new forms of qualification.

\section{PERSPECTIVES OF SUSTAINABLE TOURISM DEVELOPMENT}

The magnificent sites mentioned above constitute a real wealth of this region of Aures. For this reason, much hope can be placed in the development of tourism activities to resurrect the economy of this mountain and integrate it into the growth range of the country's favored areas. Thus, given the situation of isolation and poverty that characterizes this area and paradoxically the importance of the resources it enjoys, nature tourism can be a beneficial and significant thing regarding economic development of these deprived areas. This type of tourism does not require large upfront investments and is easily integrated with 
other rural activities in mountain regions while allowing the use of temporarily available work forces (technical and economic research office of Batna, 2005). The installation of different equipment will have a direct impact on the perception of the economy and the local populations as well as on the socio-spatial organization. Thus, targeted tourism activities can provide (create) jobs for guides, route guides, caretakers and lodging owners. It can also create bridges with other economic sectors by promoting the marketing of local products and their promotion (local products: goat cheese, honey, local cuisine and crafts).

The relaunch of employment and the increase in the professional activity of local actors directly involved (guides, carriers, managers) indirectly (craftsmen, breeders, farmers, beekeepers) could create favorable conditions to maintain population on the spot. In terms of heritage, the development of tourism activities would enhance the traditional architectural wealth and local building techniques that fit perfectly with the conditions of these environments. Thus, around the great mountainous massifs of Belezma, El Mahmel, Bouârif, Bouthleghmine, the region can offer important opportunities for sporting excursions spread over many days. Nevertheless, for the establishment of this activity it is necessary to create a small number of equipment (cottage stopover, maintenance tracks) to form guides and especially to make an effort of publicity and promotion among the interested customers at national and international level and raising awareness among the local population to supervise and manage this type of activity. The water points, the forests and the karstic landscapes can constitute privileged places for walks, picnics and relaxation.

The opening of these places to tourist activities is likely to create contacts of varied nature between the local population and the rest of the national territory as well as with the outside world. Tourism activities related to the Belezma National Park, although rudimentary, have effectively established relationships between indigenous peoples and the outside world. The owners of the orchards of Ain Berbaga and the inhabitants of this town were able to meet many tourists who frequented the famous cave of Sidi Mohammed Tahar, and to accommodate their customers the state must rehabilitate the site and access to the cave in this sense, a type of spatial arrangement has been divided as shown in (Figures 5 and 6) below.

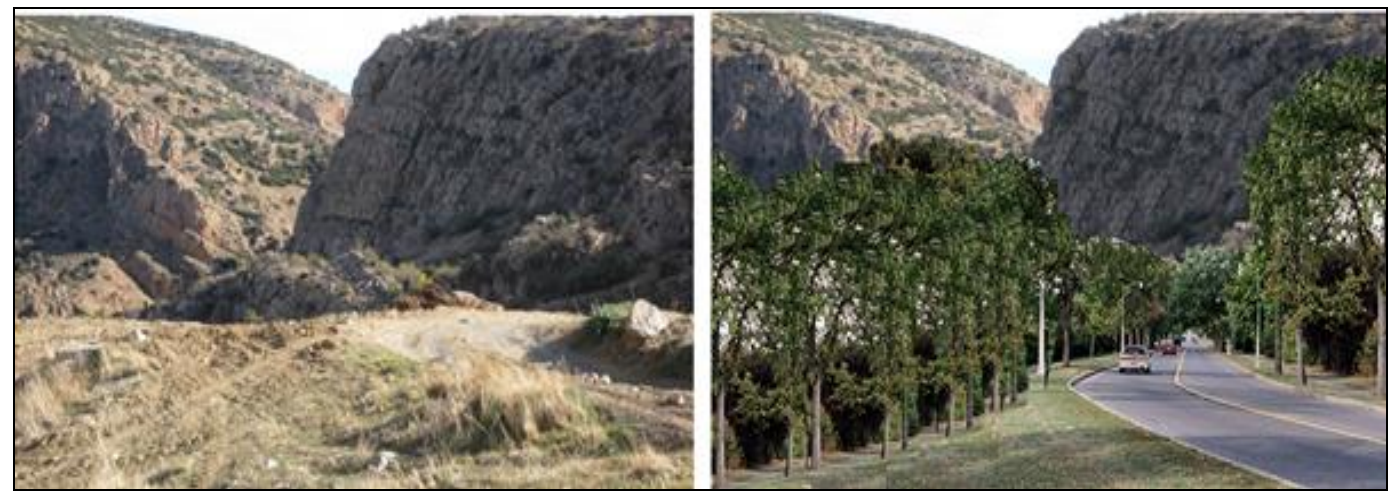

Figure 5. Access planning to Sidi Mohammed Tahar cave

The establishment of a sustainable tourism development must take place in a decentralized framework that can promote an understanding and alliance between different partners. Thus, it is a question of establishing a planning based on the consultation and the conciliation between the operators concerned by the projects of tourist development in the region of Batna. The State and its partners, the associations, the local population, and 
the investors are therefore called upon to collaborate together to guarantee the success of sustainable tourism planning stemming from a common desire to unlock the tourist and economic development of tourism and provide the local population with employment conditions and additional sources of income. Disengagement from the state and poor basic infrastructure largely explain the almost total absence of tourism projects, except for the low level of activities related to Batna's Mountains. The opening up and equipment of the region can contribute to the emergence of a series of actors and notables who can mobilize themselves for the implementation of important tourism project.

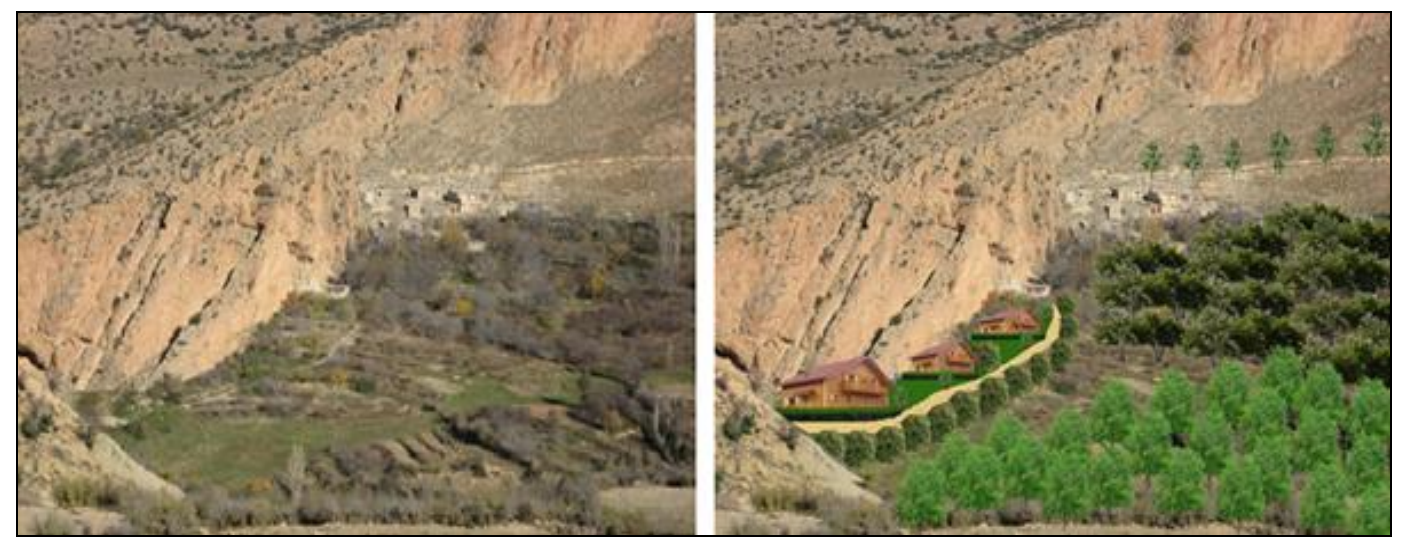

Figure 6. Development and rehabilitation of village Oucherchar's Berbaga

Thus, the State must do more in reducing territorial imbalances by giving greater importance to these peripheral areas and by encouraging tourism investments. It must ensure the provision of infrastructure (roads, drinking water, electricity, sanitation, telephone). The role of the state is also indispensable in the support of communication. The famous Geomorpho-sites as shown in Figure 6 are poorly known or even completely ignored on national and international levels. Although the tourist practices of Algerians are oriented towards the mountains, rural tourism, for which the mountain is particularly well placed, can have some success by improving the offer with a great effort of advertising and promotion. The village below Figure 7 can be a scientific center for students and researchers in earth science and ecologists.

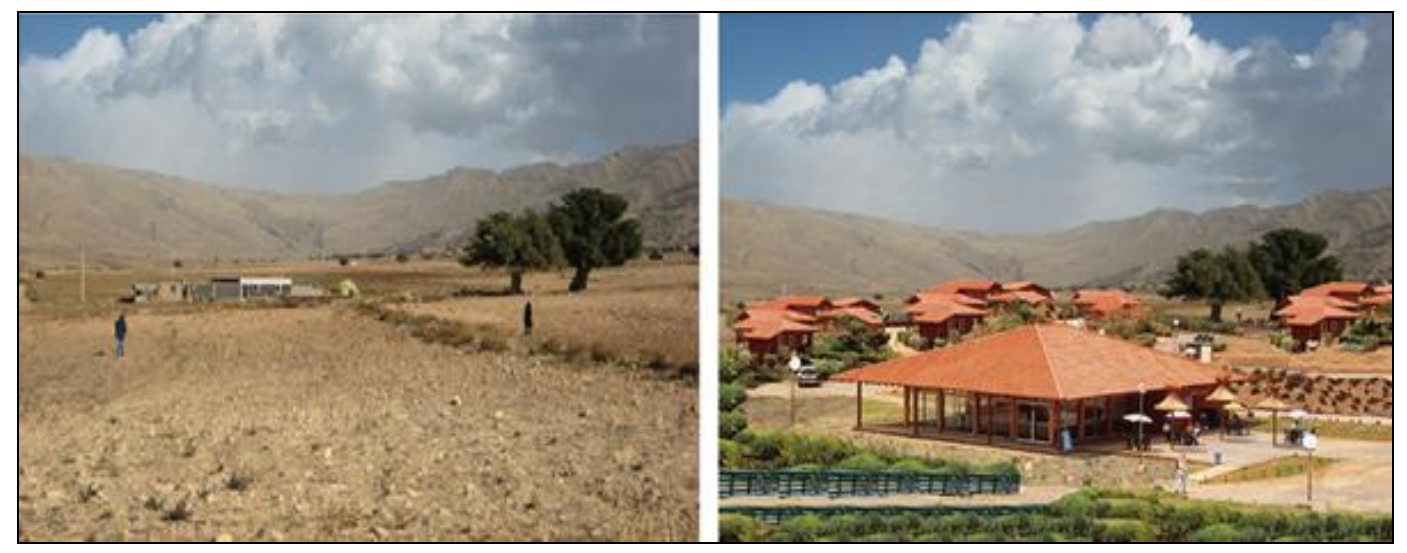

Figure 7. Site development in front of Mount el Mahmel's folds 
Finally, the State could support local investors by providing them with adapted and well-targeted technical support (information, training, assistance for tourist investment) in the form of very small funds for the development of the roads, rural lodgings or camping at the farm. The inhabitants seem to be willing to collaborate in tourist projects that would bring them more income; still their poor means are very insufficient to set up and manage projects. In the town of Oued Tagga, residents who propose the creation of an Ecolodge near source (Ain Oucherchar), in the framework of rest, show at the same time their financial inability to build and manage this project. For this purpose the investment can be made and protect the source by a system of hygiene and environmental safety through a good management of fresh water and the evacuation of liquid and solid waste. Between the mountains of the high Auressian series and at the beginning of a hilly road going towards the balconies of Ghoufi, the proposed hostel is located at the foot of the Sidi Mohamed cave. The facility has 26 rooms, so that tourists can enjoy both the natural and social environment. Here, they can enjoy the charming Mountain views, go hiking and visit archaeological sites. Enjoy traditional dishes taking advantage of the natural water flowing from the mountain of Boulthgmineas well as the orchards and a traditional mill of the Roman era, in a layout of a small plot of 30 tables. Besides, it should be remembered that these spaces cannot be managed without the effective participation of their inhabitants and under the responsibility of certain local operators. To ensure a better integration of the populations in various projects, the tourist development in the region must in no case be the business of the only exogenous investors or officials of administrative services.

The local population must really take part in the development and management of projects through elected officials, local investors or associations. The government should help the various associations acting in the region and support their cohesion to avoid fragmentation. Fifty-nine associations were created within the natural sites (Toufik, 2001). Only four of the same are still operating under very precarious conditions. The association for the environment protection set up on 1999 in Hamla down town as part of the National Fund of Rural and Agricultural Development funded by the Ministry of Agriculture through the local agricultural services (subdivision and DSA) and the CRMA (financial body) and the Belezma National Park is considered among the most active ones; these associations, which are currently supported by many young unemployed graduates, are fairly well supervised and can play an important role in the management and promotion of the tourism product.

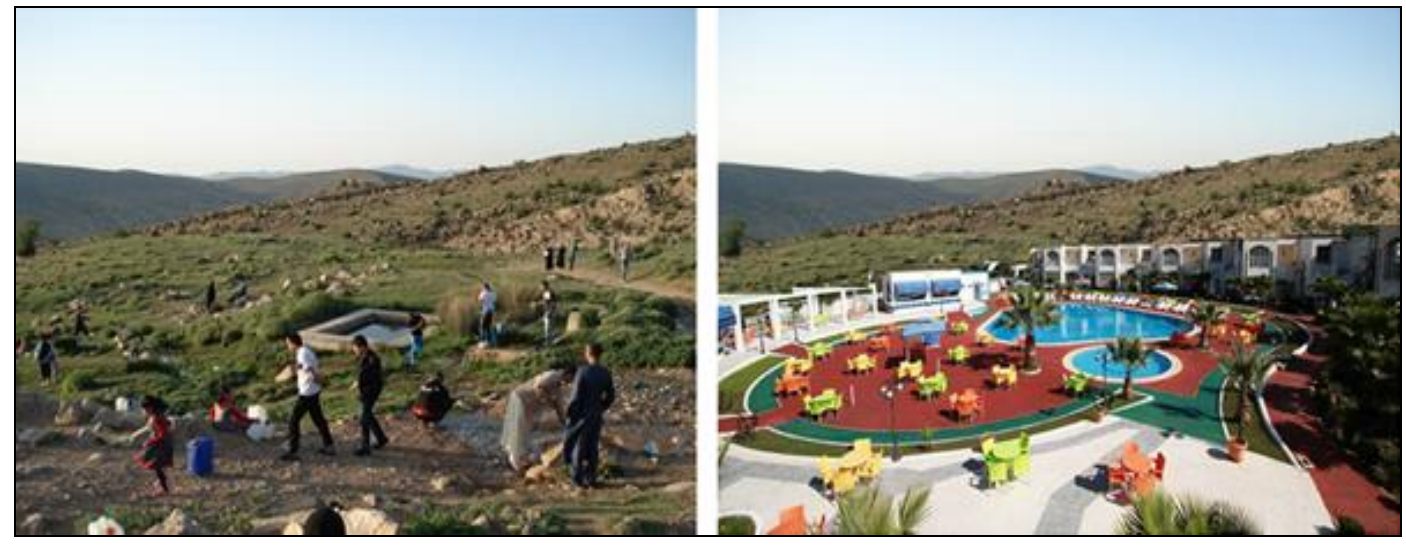

Figure 8. Development of Ain Oucherchar site for the creation of the eco-holiday village 


\section{FEASIBILITY OF PROPOSED PROJECTS}

This part of the study aims to discover the role of economic feasibility in the investment decision by taking the case of the eco-motel that has been proposed in the site of AIN OUCHERCHAR (Figure 8); to understand the importance of feasibility study and its application in the field and emphasize its importance to justify the investment decision. On this basis we choose to work on our case in a period of time estimated by 5 years.

\section{Preliminary study phase of the project:}

1. Type of project: Tourism Investment Project.

2. Project classification:

A - According to the property: The private sector responds to a general need to provide services to tourists or visitors.

B - Size: A large project depends on the mountainous nature and must be:

- Self-financing: by the investor.

- External financing: borrowing from the bank.

- Experience in the field of tourism.

C - According to the economic activity:

3. Commercial service: have commercial facilities and provide tourist services.

A - Project identification: to determine if the project should be available

- Human Resources (HR).

- Financial resources.

- Material resources.

\section{Stages of the study of the project}

4.1. Market study: In-depth study of the market to see if there is a demand for the project because tourism consumption affects several factors (salary, environment, customs, traditions, and competitors).

4.2. Technical Study: Using the project size, the technical inputs required to produce this project are identified and mapped to the resource size and location of the project.

4.3. Financial Study: This study aims to analyze the financial feasibility of the incomes and outcomes of the tourism project.

4.4. Legal Study: Considering all legal aspects of the project, we will review a set of financial criteria and indicators including the return on investment rate and the recovery period of invested funds, the net present value at the end of all these steps are decisionmaking and may be based on a financial analysis, as if the profitability of the investment and which are unprofitable is discarded as it may be on a political or strategic basis. The consulting firm studied the project for the period 2019-2023 and presented the expected cash flows for this period and the amount of the investment and the data were as follows:

Table 1. Feasibility of the environmental project of the source "Ain Oucherchar" (Data source: Technical and economic study office of Batna, 2017)

\begin{tabular}{|c|c|c|c|c|c|}
\hline year & 2019 & 2020 & 2021 & 2022 & 2023 \\
\hline $\mathrm{CF}_{\mathrm{t}}(\mathrm{DZD})$ & 48000000 & 56200000 & 76800000 & 79000000 & 82300000 \\
\hline Coefficient $\left(1+\mathrm{I}_{\mathrm{o}}\right)^{-\mathrm{n}}$ & 0.925 & 0.857 & 0.793 & 0.735 & 0.680 \\
\hline New $\mathrm{CF}_{\mathrm{t}}(\mathrm{DZD})$ & 44400000 & 48163400 & 60902400 & 58065000 & 55964000 \\
\hline$\Sigma_{\text {newCFt }}(\mathrm{DZD})$ & \multicolumn{5}{|c|}{267498400} \\
\hline
\end{tabular}

- $\mathrm{I}_{\mathrm{O}}$ Amount of the investment= 225000 ooo DZD.

- I: Discount factor $=8 \%$.

- $\quad \Sigma \mathrm{CF}_{\mathrm{t}}$ : Total cash flow generated. 
- $\mathrm{n}$ : Number of years

- DZD: Algerian Dinar

1. Net Present Value (NPV): (René, 1997):

The total net future cash flows (cash inflows minus cash outflows) received by the project at the end of the fifth year are adjusted by the discount factor representing the cost of capital or the minimum return on the investment (Aouf, 2017).

NPV (NET PRESENT VALUE) $=\Sigma \mathrm{CF}_{\mathrm{t}}-\mathrm{I}_{\mathrm{o}}$ (technical and economic study office Batna)

$\mathrm{NPV}=48000000 *(1+8 \%)-1+56200000 *(1+8 \%)-2+76800000 *(1+8 \%)$ $-3+79000000 *(1+8 \%)-4+82300000 *(1+8 \%)-5\}-225$ million

$\mathrm{NPV}=(38000000 * 0.925)+(46200000 * 0.857)+(66800000 * 0.793)+$ $(69000000) * 0.735)+(72300000 * 0.680)-225$ million

NPV $=424948$ oo DA

2. Profitability indicator ( $\left.\mathbf{I}_{\mathbf{p}}\right)$ : (René. $\left.\mathrm{D}, 1997\right)$.

$\mathrm{I}_{\mathrm{P}}=\Sigma \mathrm{CF} / \mathrm{I}_{\mathrm{O}}$

$I_{P}=267498400 / 225000000$

$\mathrm{I}_{\mathrm{P}}=1.19$

\section{Payback Period return on investment (ROI):}

This is the period during which the project recovers its invested capital through the annual net cash flow, and the shorter the period, the more useful the project is. We collect cash flows in the project until the first digit is reached before the initial cost of the project.

DZD 22.5 million -DZD 18.1 million = DZD 44 million

$\mathrm{ROI}=44000000 / 79000000\left(\mathrm{CF}_{\mathrm{t}} 4^{\text {th }}\right.$ year $)=0.56$

$0.56 * 12$ months $=6.72$ months

$0.72 * 30$ days $=21$ days

The repayment period is 3 years, 6 months and 21 days

4. Rate of return ( $R R)$ :

$\mathrm{M}_{\mathrm{f}}$ : Cumulative Accumulation of Contributions in the Last Year 2023

RR: Rate of return.

$\mathrm{M}_{\mathrm{f}}=342300000 / 5$

$\mathrm{M}_{\mathrm{f}}=68460000$

$\mathrm{RR}=68460000 / 225000000$

$\mathrm{RR}=0.30$

For every 100 DZD per investor, the project has an interest rate of 30 DZD.

\section{CONCLUSION}

Tourism activities can have an important contribution in the territorial development of this marginalized region of the Aures. They can constitute important economic stakes allowing the integration of the region and favoring a cultural and territorial link between the mountain societies and the outside world. Even so, the success of a sustainable tourism development requires the establishment of a real consultation between all the partners concerned, allowing to associate different actors in the decision-making processes concerning the development and the preservation of the tourist potentialities and all the territorial values of this mountainous area, in which tourism could be developed in four steps such as: mountain tourism, natural tourism, rural tourism and Geotourism. The profit rate index is a standard that measures the profitability of each unit of cash invested in the project: the net present value of the project being positive and the profitability index higher than the value of 1.19 , the project is economically profitable and financially advantageous. 


\section{REFERENCES}

Aouf, M. (2017). Study on the development strategy and development of tourist development zones and sites, Report, $\mathrm{N}^{\circ} 1$, p. 14.

Aouinene, A. (2012). Tourism in Algeria -potentialities and constraints- (2000-2025), within the framework of the new tourism strategy, SDAT (2025), Doctoral thesis, University of Algiers 3, p.137.

Benzeroual, B. (2006). Responsible Tourism, Environment \& Sustainable Development, study of the case of Aurès, thesis of magister in Dynamics of physical environments and natural risks, University of Batna, p. 111.

Bezza, S. (2006). The development of the tourism market in Algeria (M'sila case study). Magister thesis, Mohamed Boudiaf University, M'sila, p. 51.

Boutafenouchet, S. (2011). Littoral Jillian between imperatives of the tourist development and environmental concerns. Memory of magister of architecture and environment, Polytechnic School of Architecture and Urbanism, Algiers, p.50

Bouakrif, Z. (2012). Tourism marketing and its role in the activation of the tourism sector, the study of the case of Algeri., Thesis of magister, University of Constantine, p. 200.

Hakim, L., \& Soemarno, M. (2017), biodiversity conservation, community development and eotourism development in bromo-tengger- semeru-arjuno biosphere reserve, east Java GeoJournal of Tourism and Geosites Year X, no. 2, vol. 20, p221.

Hammed, Ch. (2012). Towards a strategy for the development of Arab tourism. Scientific communication in the framework of scientific seminar, faculty of formation, Tunisia, p 38.

Houamel, A. (2012). Contribution to the study of cedar dieback in the Batna region (case of Belezma National Park). Magister thesis in Forestry, University of Batna, p. 71.

Ilieş, D. C., Josan, N. (2009). Geosites-geomorphosites and relief. GeoJournal of Tourism and Geosites, Year II, no. 1 , vol. 3 , pp. 78-85.

Isabelle, S. (2009). Evolution of Environmental Policies and Mountain Tourism in Nepal. Journal of Alpine, Research Alpine Geography Review 97-3, p. 01.

Joleaud, L. (1934). Prehistoric Cave of Khanguet. If Mohammed Tahar (northern Aures). Journal of the Society of africanists. volume 4, booklet 1. pp. 111-114. Document generated on 09/05/2016.

Kentouche, A. (2005). Contribution to the quantitative and qualitative study of erosion in the wadi "Nafla" watershed (province of Batna). Magister thesis, university of Batna, p 55.

Kouache, Kh. (2004). The importance of tourism in the light of economic transformations, the case of Algeria. Thesis of doctorate, University of Algiers, p. 164

Leveau, Ph., Morizot, P., Morizot, J., Chamla, M., Demoulin, F., Adjali, S., \& Chaker, S. (1990). Aurès (continued). in Encyclopedia Berber Journal, p. 65.

Lindsey, P., Alexander, R., Mills, M.G.L., Romanach, S. \& Woodroffe R. (2007). Wildlife Viewing Preferences of Visitors to Protected Areas in South Africa: Implications for the role of Ecotourism in Conservation, journal of ecotourism, Vol. 6, No. 1, 2007, p 19.

Malaki, A. (2006). Geosites: Scientific interest, cultural heritage and socio-economic objectives, at Ifrane, Azrou, Aînleu and El Hajeb (atlasic average causse). Ph.D. thesis in Applied Geology, University Mohammed V - AGDAL, Morocco, p.28.

Meharzi, M. (2010). Forests, geo-systems and environmental dynamics: the case of Aurès. Ph.D. thesis on Territorial Planning - Option Physical Geography - University of Batna, p. 18.27.

Nassima, D., (2013). For an integrated development of tourism in Algeria - the case of the Algiers coastline. PhD thesis, University of Paris-Sorbonne, page 01.

René, D. (1997). Economical engineer. Edition of the polytechnic school of Montreal, p.136-138.

Sahli, M. (2004). Nature Protection and Development: Case of the Belezma National Park (Batna Mountains, Algeria). New Medit, N. 4/2004, p. 39.

Toufik, M. (2001). Livestock and Pastoralism in the Belezma National Park, Report of the National Agency for the Conservation of Nature, p. 15 .

**** Ministry of Education and Tourism, (2008). Book 5: Tourist Priority Projects, SDAT 2025, p.4.

*** Presidency, Law No. 10-02 of 16 Rajab 1431 corresponding to June 29, 2010, approval of the National Spatial Planning Scheme, in official journal of the Algerian republic $n^{\circ} 61,21$ October 2010.

Submitted:

12.02.2018
Revised:

08.06.2018
Accepted and published online 11.06.2018 